\title{
Revision and hypothetical phylogenetic analysis of the species of the New World genus Ataeniopsis (Coleoptera: Aphodiinae: Eupariini)
}

\author{
ZDZISEAWA T. STEBNICKA \\ Institute of Systematics and Evolution of Animals, Polish Academy of Sciences; Slawkowska 17, P-31 016 Krakow, Poland; \\ e-mail: stebnicka@isez.pan.krakow.pl
}

Key words. Coleoptera, Scarabaeidae, Aphodiinae, Eupariini, Ataeniopsis, new species, new combinations, taxonomy, phylogeny, distribution, New World

\begin{abstract}
The New World genus Ataeniopsis Petrovitz, 1973 is revised. Fifteen species are recognized including three new species: Ataeniopsis carupanoi $\mathrm{sp}$. n. from Venezuela, A. jaltipani $\mathrm{sp}$. n. from Mexico and A. vinacoensis $\mathrm{sp}$. $\mathrm{n}$. from Argentina. Lectotype of A. haroldi (Steinheil, 1872) is designated, the name of type species A. notabilis Petrovitz, 1973 is reestablished, five species are given in a new combination. The taxa are diagnosed, keyed and illustrated, and biological information and distribution data summarized following the species descriptions. A hypothetical phylogenetic analysis of Ataeniopsis based on cladistic analysis is presented.
\end{abstract}

\section{INTRODUCTION}

This revision of the genus Ataeniopsis Petrovitz, 1973, is one of a series of papers published on the Neotropical Eupariini (Stebnicka, 1999a, 1999b, 2000, 2001a, 2001b, 2001c, 2002). The genus with the type species Ataeniopsis notabilis Petrovitz, 1973 from Brazil, consists of a species complex structurally distinct from other genera of the Eupariini. Woodruff (1973) and Cartwright (1974) placed the North American species in the genus Ataenius Harold, 1867. Chalumeau (1992) treated Ataeniopsis as a subgenus of Ataenius, however, a number of consistent characters appear to warrant generic status. The genus contains fifteen currently recognized species ranging in distribution from the United States to Argentina. Seven species are found in South America, four in Mesoamerica and in the Sonoran province, three species occur exclusively in the southeastern United States and one species inhabits the West Indies. This study considerably extends the distribution of Ataeniopsis which is presented in the form of maps, with the exception of species inhabiting the United States of America cited by Cartwright (1974). A generic diagnosis is given below, followed by a cladistic analysis, keys and descriptions. Since the species of Ataeniopsis are not clearly differentiated, their descriptions include mainly: exceptions to the usual conditions mentioned in the generic diagnosis, the state of characters varying widely in the genus and unique features.

\section{Collections studied}

Approximately 1700 members of Ataeniopsis were selected from New World material consisting of nearly 20 000 identified specimens, including all available type specimens. The following institutions and private collections kindly contributed material for this study. The abbreviations cited below are used in all text citations:

BCP Balthasar's Collection, National Museum, Prague

\section{CMN Canadian Museum of Nature, Ottawa}

FMLT Fundacion Miguel Lillo, Tucumán, Argentina

FSCA Florida State Collection of Arthropods, Gainesville

HAHC Henry \& Anne Howden Collection, Ottawa

HNHM Hungarian Natural History Museum, Budapest

ISEA Institute of Systematics and Evolution of Animals PAS, Krakow

JSC Joachim Schulze Collection, Berlin

MHNG Museum d'Histoire naturelle, Geneva

MNHN Museum national d'Histoire naturelle, Paris

MZUSP Museu de Zoologia, Universidade de Săo Paulo

NRS Naturhistoriska Rijksmuseet, Stockholm

PEMD P.I.M.E. Entomological Museum, Detroit

PSC Paul Skelley Collection, Gainesville

SMTD Staatliches Museum für Tierkunde, Dresden

UMB University of Mississippi, Biology Department, Mississippi

USNM United States National Museum of Natural History, Washington DC

WWC William Warner Collection, Arizona, Chandler

ZMHB Zoologisches Museum für Naturkunde der Humboldt Universität, Berlin

\section{TAXONOMY AND PHYLOGENY}

Genus Ataeniopsis Petrovitz, 1973

Ataeniopsis Petrovitz, 1973: 190.- Dellacasa, 1988: 270 (catalogue); Stebnicka 1999c : 293.

Euparia Le Peletier St.-Fargeau \& Serville, 1828: 357 (partim).

Ataenius Harold, 1867: 82 (partim).

Type species. Ataeniopsis notabilis Petrovitz, 1973, by original designation. 
Diagnosis. Length $2.8-4.8 \mathrm{~mm}$. Body (Fig. 2) slender, moderately convex, strongly shiny, colour reddish brown to black, legs reddish brown. Head trapezoid, relatively small, weakly gibbose medially; clypeal edge usually dentate on each side of shallow median emargination, rarely angulate or obtusely rounded; surface of head transversely wrinkled, frontal area punctate. Eyes moderate in size. Pronotum subquadrate, anterior angle obtuse, posterior angle broadly rounded toward base, side margin not fimbriate, base margined or not, sometimes minutely crenate; pronotal surface punctate, punctures never contiguous or confluent. Elytral humeral denticle very small or missing, basal bead very weak or lacking; striae and strial punctures very fine to fine, intervals flat or only slightly convex, minutely punctate or impunctate. Flight wings well developed. Scutellum pentagonal, shiny. Prosternum and inner side of profemur with pale hair, prosternal process triangular, acutely prominent medially; mesosternum lower than metasternum, finely shagreened; mesocoxae approximate, meso-metasternal carina short and fine; metasternal plate smooth, shiny, disc convex; lateral metasterna 1 triangle shallow, usually very finely roughened inside; abdominal sternites polished, shiny, usually impunctate, sutures of sternites very fine, shallow, with very fine fluting, sternites usually differ in length; pygidium convex, strongly shiny, surface polished, sometimes slightly swollen or scarcely punctate. Profemur (Fig. 3) polished without anterior and posterior lines, anterior edge ends in slightly transparent sclerite, surface smooth; meso- and metafemur fusiform without postfemoral lines; protibia with relatively long lateral teeth and terminal spur, protarsus long; meso- and metatibia dorsoventrally flattened, apex with fringe of setae, accessory spine usually lacking, spurs thin; basal tarsomere of metatarsus always longer than upper tibial spur. General type of epipharyngeal structures as in Fig. 4. Male genitalia (Figs 5-11, 14-20) moderately differentiated, slender; phallus (Fig. 5) furnished with soft sclerites and spicules, parameres usually sinuate. Sexual differences indicated in the length of abdominal sternites.

Remarks. Ataeniopsis is most closely related to Ataenius but exhibits a number of apomorphies, some unique and some in combinations that universally apply to all species of the genus. The best characters combinations that make members of Ataeniopsis easy to recognize are: the elongate and highly polished body, the abdominal sternites with very fine sutures, the pygidium convex, shiny with no scabrous sculpture, and all femora lack marginal lines.

The vast majority of specimens from Central and South America were collected using light traps, which provide some information on their flight period but very little on their microhabitat.

\section{Phylogenetic hypothesis}

On the basis of the characters judged to be derived the genus Ataeniopsis is regarded as a monophyletic group. Fifteen species of Ataeniopsis form ingroup and five species belonging to Ataenius texanus-group the outgroup (synapomorphies: size and shape of the body, sculpture of the head). The 22 characters with 47 character states hypothesized to be primitive and derived, are defined and coded in Table 1.

\section{Table 1}

Matrix of taxa and character states used in the cladistic analysis.

1. Body shape - parallel-sided $(0)$, not parallel-sided (1); 2. Clypeal surface - smooth (0), microreticulate (1); 3. Clypeal anterior edge - denticulate (0), angular (1), rounded (2); 4 . Clypeal wrinkles - coarse (0), fine (1); 5. Punctures on vertex - close (0), scattered (1); 6 . Pronotum, basal margin - present $(0)$, absent (1); 7. Pronotum, basal edge - crenate (0), smooth (1); 8. Pronotum, spacing of punctures - one diameter $(0)$, more than one diameter $(1) ; 9$. Pronotum, lateral surface punctate $(0)$, smooth (1); 10. Elytra, humeral denticle present $(0)$, absent (1); 11. Elytral striae - deep (0), shallow (1); 12. Elytral intervals, punctures - distinct (0), indistinct (1); 13. Elytra length to pronotum length -2.5 times longer (0), 3 times longer (1); 14. Prosternal hair short (0), long (1); 15. Metasternal midline - deep (0), shallow (1); 16. Abdominal sternite fluting - moderate (0), fine (1), absent (2); 17. Pygidium disc - scabrous (0), punctate (1), smooth (2); 18. Metafemur length to mesofemur length - equal $(0)$, longer $(1) ; 19$. Metatibia at apex - slightly widened (0), expanded (1); 20. Profemur, anterior sclerite - absent (0), present (1); 21. Metafemur posterior line - present $(0)$, absent $(1) ; 22$. Metatarsus, length of basal tarsomere to upper tibial spur - equal (0),

\begin{tabular}{|c|c|c|c|c|c|}
\hline \multirow[t]{2}{*}{ Characters } & $\ldots$ & $\ldots 1$ & 11111 & 11112 & 22 \\
\hline & 12345 & 67890 & 12345 & 67890 & 12 \\
\hline Outgroup & 00000 & 00000 & 00000 & 00000 & 00 \\
\hline Ataeniopsis armasi & 00011 & 01110 & 01111 & 12001 & 11 \\
\hline $\begin{array}{l}\text { Ataeniopsis } \\
\text { carupanoi sp.n. }\end{array}$ & 00011 & 00111 & 11001 & 02101 & 11 \\
\hline Ataeniopsis duncani & 00010 & 01110 & 11110 & 12001 & 11 \\
\hline Ataeniopsis edistoi & 10210 & 01000 & 11010 & 02001 & 11 \\
\hline Ataeniopsis figurator & 10110 & 01011 & 10001 & 02001 & 11 \\
\hline Ataeniopsis haroldi & 00011 & 01110 & 01111 & 02001 & 11 \\
\hline Ataeniopsis jaltipani sp.n. & 00011 & 11101 & 01111 & 22101 & 11 \\
\hline Ataeniopsis notabilis & 01011 & 10100 & 11000 & 21001 & 11 \\
\hline Ataeniopsis parallelus & 01000 & 00001 & 00001 & 01101 & 11 \\
\hline Ataeniopsis parkeri & 00010 & 01110 & 11110 & 12001 & 11 \\
\hline Ataeniopsis pusillus & 01200 & 01000 & 00001 & 12101 & 11 \\
\hline Ataeniopsis regulus & 01011 & 00100 & 11001 & 01101 & 11 \\
\hline Ataeniopsis rugopygus & 01000 & 01001 & 00111 & 02011 & 11 \\
\hline Ataeniopsis saxatilis & 10210 & 01111 & 11001 & 12011 & 11 \\
\hline $\begin{array}{l}\text { Ataeniopsis } \\
\text { vinacoensis sp.n. }\end{array}$ & 00011 & 01110 & 00110 & 02001 & 11 \\
\hline
\end{tabular}

longer (1).

The analysis was run using the heuristic option in Winclada 0.9.9 (Nixon, 1999) combined with Nona (Goloboff, 1993), including 100 replicative searches for trees under ACCTRAN optimization. Six equally parsimonious cladograms were generated, each of length $=58$, $\mathrm{CI}=43$ and $\mathrm{RI}=59$, suggesting a monophyletic origin of Ataeniopsis. This hypothesis is supported by synapomor- 


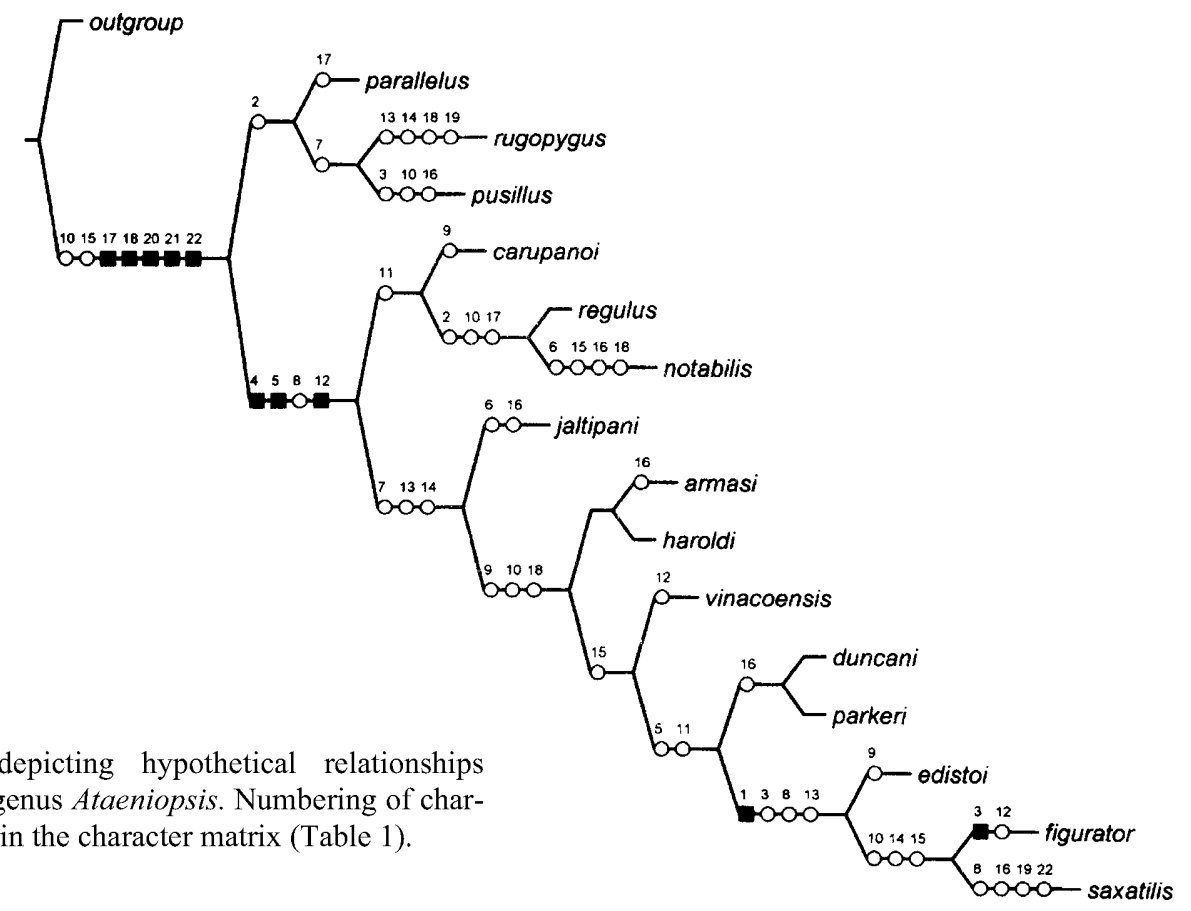

phies, which are discussed relative to the presented cladogram (Fig. 1) as follows:

Character 17 - pygidium polished, shiny; this apomorphic state is found in all members of Ataeniopsis, only

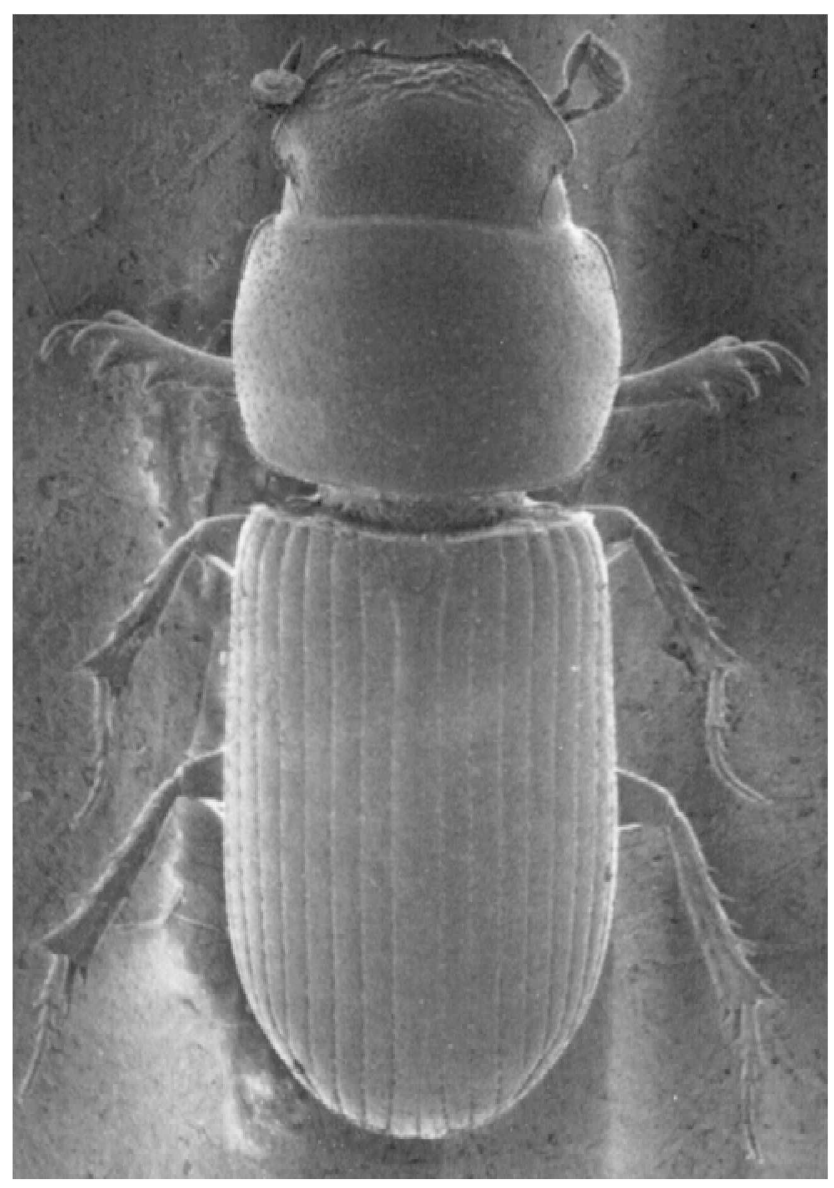

Fig. 2. Ataeniopsis pusillus - habitus. parallelus and regulus + notabilis have a row of punctures at base of the pygidial disc. Plesiotypically, in all other euparine species including the outgroup, the disc of pygidium is scabrously eroded. Character 18 - metafemur longer than mesofemur. Although this state is variably developed in the Aphodiinae, it is synapomorphic for the genus with subsequent change to homoplasies for most species. Character 20 - profemur anteriorly with apical sclerite in place of marginal groove. This apomorphic state is found in all species of Ataeniopsis. Plesiotypically, all other euparine species have the profemur margined and more or less deeply grooved. Synapomorphy for the clade with no reversals. Character 21 metafemur lacking posterior line; synapomorphy for the clade with no reversals. A similar character, though variably developed, is found in various members of the euparine genera but none of the Ataeniopsis species has a trace of postfemoral line. Character 22 - basal tarsomere of posterior tarsus longer than upper tibial spur. Character variable throughout the Eupariini; its state is apomorphic at this level of analysis and synapomorphic for the clade with one reversal to plesiomorphic condition in saxatilis.

Synapomorphies for the following main lineage of Ataeniopsis are:

Character 4 - clypeal wrinkles fine. This state occurs in most Ataeniopsis species except for the parallelus + rugopygus + pusillus node, which is not supported by synapomorphies. These three species have shagreened and usually roughly sculptured head like the outgroup taxa. Character 5 - vertex of head with scattered punctures; synapomorphy for nodes formed by carupano + regulus + notabilis and jaltipani + armasi + haroldi + vinacoensis. Plesiotypically, the punctures on vertex are dense and occur in a regular band; this character state concerns the nodes formed by two Sonoran species duncani + parkeri and by three Nearctic species edistoi + 
figurator + saxatilis. Character 12 - elytral intervals smooth, impunctate. The apomorphic state that typifies most species of Ataeniopsis; synapomorphy with reversals in vinacoensis and figurator, which have the elytral intervals with more or less visible punctures. Character 1 - body slightly arcuate, not quite parallel-sided. The apomorphic character state and synapomorphy for the node formed by edistoi + figurator + saxatilis, the three species known exclusively from the southeastern United States. The remainder of the species in the ingroup and outgroup have a slender and parallel-sided body. The species of Ataeniopsis share a number of character states that are probably plesiomorphic and the retention of which serves as a reflection of their relatedness.

\section{KEY TO THE SPECIES OF ATAENIOPSIS}

1 Body parallel-sided . . . . . . . . . . . . . . 2

- Body not quite parallel-sided ............... 13

2 Length 2.8-3.0 mm; surface of body finely shagreened, clypeus minutely dentate on each side of median emargination; punctures of pronotum separated by less than one diameter; Brazil . ................. parallelus

- Length 3.2-4.8 mm; surface of body polished, not shagreened; clypeus dentate or obtuse on each side of median emargination; punctures of pronotum separated by one diameter or more $\ldots \ldots \ldots \ldots \ldots \ldots \ldots \ldots \ldots . \ldots$

3 Clypeus obtuse, lacking denticles, clypeal surface roughly sculptured; Argentina, Bolivia, Paraguay, Uruguay A. pusillus

- Clypeus denticulate, clypeal surface variously sculptured

4 Clypeal surface with coarse transverse wrinkles broken into short segments; surface of pygidium swollen; USA, Mexico

A. rugopygus

- Clypeal surface with fine, contiguous transverse wrinkles; surface of pygidium evenly convex, punctate or smooth . 5

5 Base of pronotum without marginal line; abdominal sternites without fluting along sutures $\ldots \ldots \ldots \ldots \ldots 6$

- Base of pronotum with marginal line; abdominal sternites distinctly or inconspicuously fluted along sutures . . . . 7

6 Head minutely shagreened, subopaque; elytra about 2.5 times as long as pronotum; pygidium with few moderate punctures along median carina; Bolivia, Brazil

A. notabilis

- Head not shagreened, shiny; elytra about 3 times as long as pronotum; pygidium polished without punctures

7 Elytra about 2.5 times as long as pronotum ........ 8

- Elytra about 3 times as long as pronotum ......... 9

8 Head minutely shagreened, almost opaque; abdominal sternites distinctly fluted along sutures; pygidium punctate along median carina; Brazil, Ecuador, Guyana, Peru, Venezuela ..................... A. regulus

- Head slightly microreticulate, shiny; abdominal sternites inconspicuously fluted along sutures; pygidium without punctures; Venezuela ............ A. carupanoi $\mathrm{sp.} \mathrm{n}$.

9 Clypeal emargination between denticles wide, gena promi-

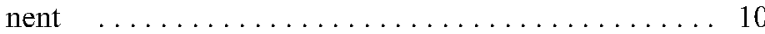

- Clypeal emargination between denticles moderate in width, gena not prominent . . . . . . . . . . . . . . 11

10 Base of elytra as wide as pronotal base; Argentina, Bolivia, Paraguay . . . . . . . . . . . . . . . . A Aroldi

- Base of elytra narrower than pronotal base; Argentina .... $\ldots \ldots \ldots \ldots \ldots \ldots \ldots$. . vinacoensis sp. $\mathrm{n}$.
11 Abdominal sternites 2,3 smooth, sternites 4, 5 minutely fluted along sutures; West Indies $\ldots \ldots \ldots \ldots$. armasi Abdominal sternites 2-5 finely fluted along sutures . . . 12

12 Colour usually castaneous; pronotal punctures few, scattered, almost completely lacking in anterior discal area; USA, Mexico .................... parkeri

- Colour usually piceous; pronotal punctures numerous, evenly distributed in discal area; USA, Mexico

A. duncani

13 Clypeus subdenticulate or angulate on each side of median emargination; Eastern states west to New Mexico, Oklahoma, Texas ................. A. figurator

- Clypeus broadly rounded on each side of median emargination $\ldots \ldots \ldots \ldots \ldots \ldots \ldots \ldots \ldots \ldots \ldots$

14 Pronotal punctures strong, close, evenly distributed; pygidium with few shallow, moderate punctures: South Carolina ........................ edistoi

- Pronotal punctures very moderate, scattered; pygidium polished; Georgia, South Carolina, North Carolina ........ .............................. saxatilis

\section{Ataeniopsis haroldi (Steinheil, 1872)}

(Figs 3-6, 12)

Ataenius haroldi Steinheil, 1872: 556.- Harold 1874: 17; Schmidt 1922: 453; Chapin 1940: 15 (not Steinheil, 1872); Dellacasa, 1988: 138 (catalogue); Deloya 1994: 49 (not Steinheil, 1872);

Ataenius (Ataeniopsis) haroldi: Chalumeau 1992: 196 (nota).

Type material. Lectotype male (here designated), labelled "Argentina, Mendoza", "Coll. C.Felsche Kauf. 20, 1918", "Ataenius haroldi Steinh.", in SMTD. Paralectotypes (3), same data as lectotype, in SMTD.

Other specimens examined (105). Argentina - Mendoza (no additional data) (ISEA, SMTD, ZMHB); Prov. Salta, Dpto Oran, Rio Pescado, VI.1944, D. Vellard (FMLT), Rosario de Lerma, 1325 m, 9.III.1982, H.\& A. Howden (CMN); Prov. Tucumán, Dpto Capital, Puente Rio Sali, XI.1950, coll. Martinez (CMN); Prov. La Rioja, Illisca, 8.I.1980, L.A.Stange (ISEA), Dpto Rosario, Penaloza, Sierra de Argana, El Rocillo, 20.X.1987, Irwin \& Parker (USNM); Prov. Chaco, Resistencia, Chaco Nat. Park, 16.XII.1990, S.\& J. Peck (CMN); 12.XI.1950, A. Willink (FMLT); Prov. Cordoba, $4 \mathrm{~km} \mathrm{NE} \mathrm{Cruz} \mathrm{del} \mathrm{Eje,}$ 20.II.1982, H.\& A. Howden (CMN); Prov. Formosa, $50 \mathrm{~km} \mathrm{NW}$ Clorinda, P.N. Rio Pilcomayo, 17.XII.1990, S.\& J. Peck (CMN, ISEA); Prov. Jujuy, 17 km S Ledesma, 500 m, 27.XII.1987, S.\& J.Peck (CMN). Bolivia - $10 \mathrm{~km} \mathrm{~W} \mathrm{Portachuelo,} \mathrm{27.III.1978,}$ G.B. Marshall (ISEA, USNM); Santa Cruz, Saavedra Res. Sta., 25.III.1978, O'Brien \& Serrate (ISEA); Beni, $40 \mathrm{~km}$ E San Borja, Est. Biol. Beni, El Porvenir, 6-8.IX.1987, W.E. Steiner (USNM); Santa Cruz, $5 \mathrm{~km}$ ESE Warnes, Hotel Rio Selva, 20.X.2000, M.C. Thomas; $10 \mathrm{mi} \mathrm{W}$ Pto Banegas, 25.III.1978, G.B. Marshall (FSCA); Santa Cruz, $13 \mathrm{~km}$ SE Santa Cruz de la Sierra, 26.III.1998, H.\& A. Howden (CMN); Santa Cruz, Buena Vista, 380 m, 20.II.1999, L. Stange; 28.XI.1998, V. Tichy (JSC, PSC). Paraguay - Dpto Boqueron; Central Capiata, 29.I.1996, C. Aguillar (CMN).

Diagnostic characters. Length $4.2-4.8 \mathrm{~mm}$. Clypeal denticles usually well developed, acute; clypeal surface finely wrinkled over median convexity, vertex of head with irregularly spaced punctures. Pronotum subquadrate, basal marginal line distinct, smooth; surface punctures mixed minute, fine and moderate, irregularly spaced, usu- 


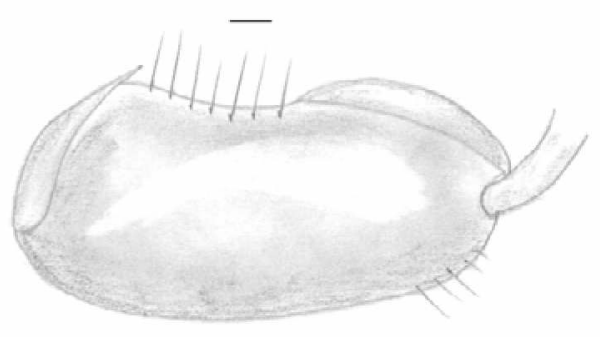

3

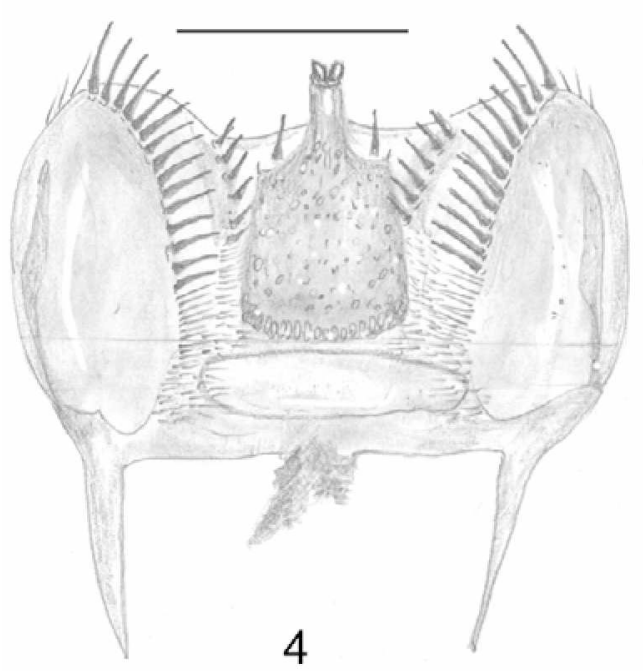

8

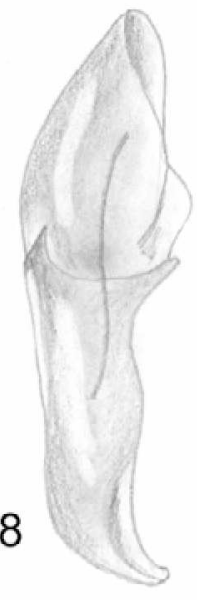

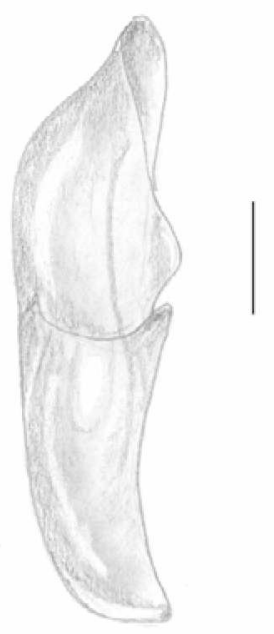

6

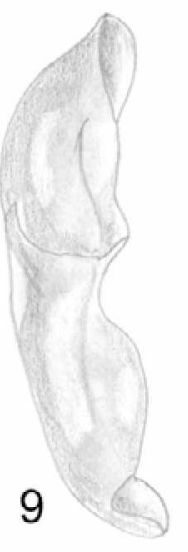

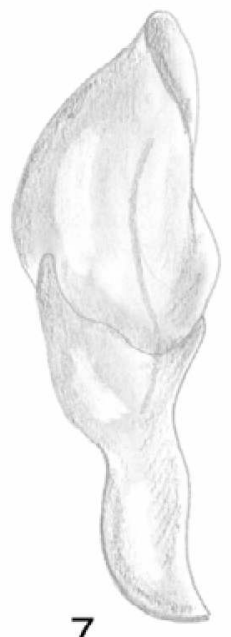

7
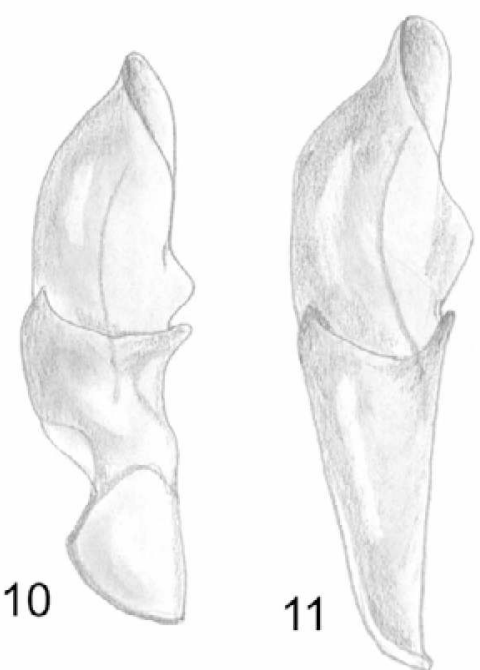

Figs 3-11. 3-6: Ataeniopsis haroldi. 3 - left profemur; 4 - epipharynx; 5 - penis; 6 - aedeagus in lateral view. 7-11: Aedeagi in lateral view. $7-$ A. regulus; $8-$ A. notabilis; $9-$ A. pusillus; $10-$ A. parallelus; $11-A$. vinacoensis $\mathrm{sp}$. $\mathrm{n}$. Scale lines: $0.25 \mathrm{~mm}$.

ally separated by $2-3$ diameters but variable in density, middle of lateral area lacks punctures or only very fine punctures visible. Elytra relatively long, parallel, striae usually distinctly impressed with punctures slightly crenating inner margins of intervals; discal intervals flat, shiny, minute punctures scattered or lacking. Prosternum and inner side of profemur with long pale hair; metasternal midline shallow, sometimes disc of metasternum slightly concave; abdominal sternites distinctly fluted along sutures, surface slightly swollen at extreme sides. Profemur, meso- and metafemur fusiform, equal in length; metatibia slender, apex in some specimens with very minute accessory spine; basal tarsomere of metatarsus equal in length to following three tarsomeres combined. Epipharynx as in Fig. 4.

Male. Abdominal sternite 3 longer than sternite 4; sternite 5 half length of sternite 4. Genitalia as in Figs 5-6.
Female. Body usually more elongate than in male; abdominal sternites 2-4 equal in length, sternite 5 half length of sternite 4 .

Remarks. Ataeniopsis haroldi is one of the larger species of the genus occurring south of the Amazon basin (Fig 12). It was considered as a widely distributed species, recorded by Chapin (1940) from Mexico, Cuba, Hispaniola, Puerto Rico and North America. Deloya (1994) followed Chapin in citing this misleading distribution without critical comment. As indicated on the labels, the specimens were collected to light traps in subtropical seasonal forest and in riverine forest and beaten from leaves.

\section{Ataeniopsis regulus (Balthasar, 1947)}

(Figs 7, 12)

Ataenius regulus Balthasar, 1947: 53.- Dellacasa, 1988: 280 (catalogue). 


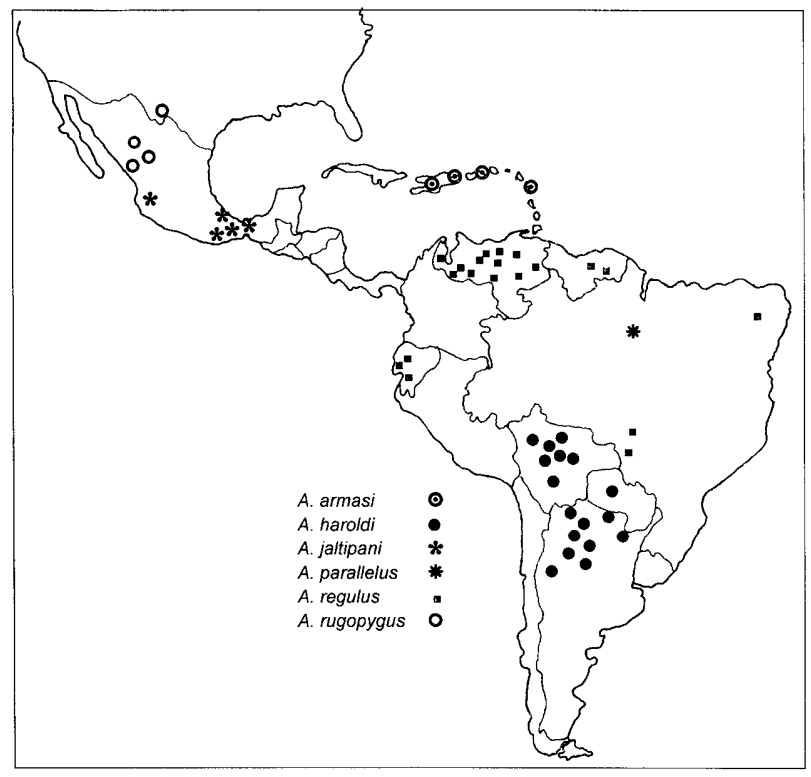

Fig. 12. Known distribution of Ataeniopsis in Central and South America.

Ataenius (Ataeniopsis) regulus: Chalumeau, 1992: 196198.

Ataenius bordoni Petrovitz, 1972: 166 ; Chalumeau 1992: 196 (as synonym of $A$. regulus)

Ataenius abdominalis Petrovitz, 1973: 154; Chalumeau 1992: 196 (as synonym of $A$. regulus)

Type material. Ataenius regulus: holotype (sex not determined), labelled "Venezuela", "Ataenius regulus n. sp. Dr. V. Balthasar det.", in BCP. A. bordoni: holotype (sex not determined), labelled "Venezuela, Cagua (Edo Aragua) 28.IX.60, Bordon", "Ataenius bordoni nov. Petrovitz", in PEMD (not seen by the author). Paratypes (3) same data as holotype, in MHNG A. abdominalis: holotype (sex not determined), labelled "Brasil, Piaui Terezina 3.VIII.1953", "Ataenius abdominalis m. Petrovitz", in MZUSP. Paratypes (3), same data as holotype, in MHNG.

Other specimens examined (393). Brazil - (MT) Mato Grosso, Varzea Grande Co., Cuîaba, 7.IV.1972, W.M. Whitcomb (FSCA); Corumba (MHNG). Ecuador - Guayas, Prov. Guayaquil, 50 m, 1-2.III.1981, H. \& A. Howden; Guayas, 12 km N Playas, 23.VII.1976, S.\& J. Peck; Guayas, El Oro Prov., 1 km N Machala 19,II.1981, H.\& A. Howden (CMN). Guyana (no additional collection data) (ZMHB); Lethem, bank of Takutu River, 5.IV.1994, P.S. Spangler (USNM). Peru - Loreto, Yacumama Lodge near junction Rio Maranon \& Rio Ucayali, 6-20.VIII.1994, P. Skelley (ISEA, PSC). Venezuela - Apure, Hato del Frio, 21.I.1980, leg. Bordon (ISEA); Hato del Frio, Hwy between Montecal and El Saman, 7.VI.1988, M. Epstein (USNM); Cagua (Edo Aragua) 10.X.1960, leg. Cermell (ISEA); Guarico, La Palmita, 28.XII.1970, leg. Bordon (ISEA); Guarico, $12 \mathrm{~km}$ W Valle de la Pascua, 21-22.VI.1996, H.\& A. Howden (CMN); Guarico, Coroso Pando, 8 km N, 17-18, .IV. 1984, F.W. Eiland \& V. Linares (USNM); Calabozo, Farm La Linde, 6.IX.1996, leg. Thiemicke (ISEA); Guarico, $12 \mathrm{~km} \mathrm{~S} \mathrm{Calabozo,}$ 6-12.II.1969, Est. Biol. Los Llanos, P. Spangler (ISEA, USNM) Merida, Palmarito, Lake Maracaibo 1 m, 3.VIII.1989, S. J. Peck (CMN); Falcon, Tucacas, 1 m, 4.VIII.1989, S.J. Peck (CMN); Bolivar, Guri, 11.VI.1998, H.\& A. Howden (CMN).
Diagnostic characters. Length $3.2-4.0 \mathrm{~mm}$. Colour reddish black to black, legs usually markedly lighter than bottom surface. Clypeal emargination shallow, denticles usually very fine, in older specimens retuse; surface of head distinctly microreticulate, subopaque, frontal suture marked by line; clypeal wrinkles very fine, punctures on vertex variable in density, usually irregularly spaced. Pronotum slightly transverse, basal marginal line distinct, edge finely crenate, crenations visible when pronotum viewed from behind; pronotal punctures variable, usually fine along anterior margin and larger toward base and sides, mixed fine and moderate, irregularly spaced. Elytra parallel, about 2.5 times as long as pronotum, striae shallow with fine punctures; discal intervals flat, shiny, surface punctures very minute. Prosternum and inner side of profemur with short hair; metasternal midline weakly marked, sometimes disc of metasternum slightly concave; abdominal sternites distinctly fluted along sutures, surface slightly swollen at extreme sides, pygidium with few moderate to coarse punctures along median carina, apical lip convex. Meso- and metafemur fusiform with fine scattered punctures, metafemur slightly longer than mesofemur; metatibia slender, apex in some specimens with very minute accessory spine; basal tarsomere of metatarsus a trifle longer than following three tarsomeres combined.

Male. Abdominal sternite 3 shorter than sternite 2, longer than sternite 4 and 5; sternites 4,5 equal in length; pygidium longer and more convex than in female. Genitalia as in Fig. 7.

Female. Abdominal sternite 3 longer than sternite 4; sternites 4 and 5 equal in length.

Remarks. Variation in Ataeniopsis regulus is considerable, both within a locality and between widely separated localities. The populations from Ecuador differ from those of Venezuela, showing variation in size and in the punctuation of pronotum and may at first glance appear to be separate species. Such variation is observed among other species of the Neotropical Aphodiinae and it is undoubtedly due to the different environmental conditions. A. regulus is one of the most common species of Ataeniopsis, closely related to A. carupanoi sp. n. and to A. notabilis (see Remarks under those species). All specimens with collection data were taken at UV lights, on coastal area of lagoon and lakes, in coconut groves.

\section{Ataeniopsis notabilis Petrovitz, 1973}

(Figs 8, 13)

Ataeniopsis notabilis Petrovitz, 1973: 191.- Dellacasa 1988: 170 (catalogue).

Ataenius (Ataeniopsis) notabilis: Chalumeau 1992: 196 (as synonym of $A$. regulus).

Type material. Holotype female, labelled "Sete Lagôas M.G. Brasil, XI.1963, G.R. Kloss", "Ataeniopsis n.g notabilis Petrovitz", in MHNG.

Other specimens examined (48). Bolivia - Beni, $40 \mathrm{~km} \mathrm{E}$ San Borja, Est. Biol. Beni, El Porvenir, 6-8.IX.1987, W.E. Steiner (ISEA, USNM); El Beni, Sin. Palm Camp, NE of San Borja, 6-9.VIII.1988, R.W. Brooks (USNM). Brazil - (MT) Mato Grosso, Varzea Grande Co., Cuiaba, 7.IV.1972, W.M. Whitcomb (FSCA). 


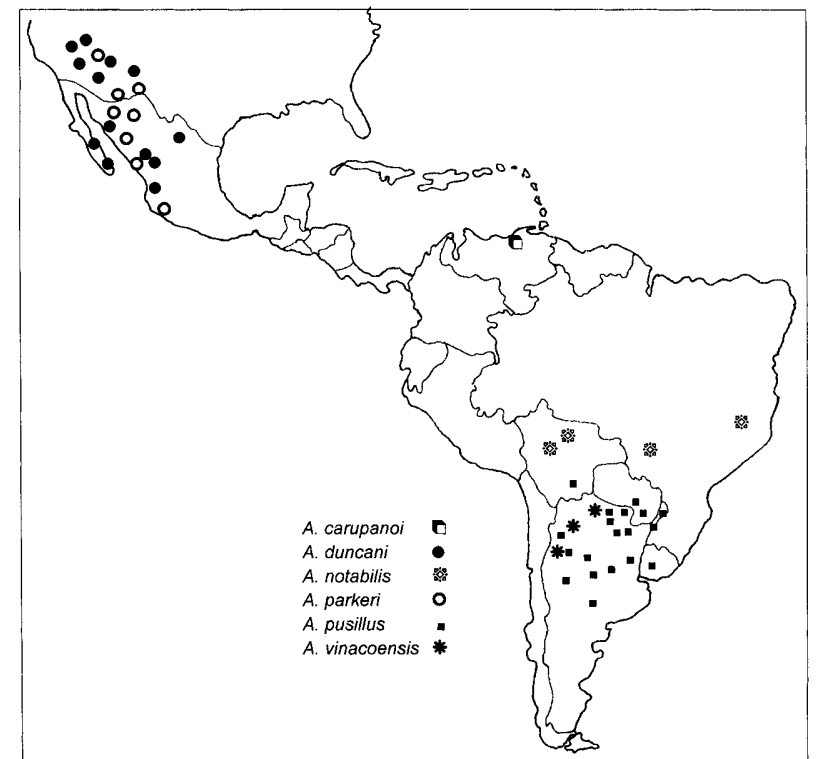

Fig. 13. Known distribution of Ataeniopsis in Central and South America.

Diagnostic characters. Length $3.2-3.8 \mathrm{~mm}$. Colour reddish black to black, legs usually lighter than bottom surface. Clypeal emargination shallow, denticles usually very fine, surface of head finely microreticulate, subopaque, frontal suture not indicated, clypeal wrinkles fine, punctures on vertex variable in density, usually irregularly spaced. Pronotum slightly transverse, basal marginal line absent, basal edge finely crenate, crenations visible when pronotum viewed from behind; pronotal punctures variable, usually fine along anterior margin and larger towards base and sides, mixed fine and moderate, irregularly spaced, fine and shallow at anterior angle and along lateral margin. Elytra parallel, about 2.5 times as long as pronotum, striae shallow with fine punctures; discal intervals flat, shiny, surface punctures very minute. Prosternum and inner side of profemur with short hair; metasternal midline shallowly impressed; abdominal sternites without fluting, almost smooth along sutures, surface smooth, impunctate; pygidium with 3-4 fine punctures along median carina, apical lip convex. Mesoand metafemur equal in length, fusiform with fine scattered punctures; metatibia slender, apex without accessory spine; basal tarsomere of metatarsus a trifle longer than following three tarsomeres combined.

In both sexes abdominal sternites 4 and 5 equal in length, shorter than sternite 3. Male genitalia as in Fig. 8.

Remarks. Chalumeau (1992) synonymized Ataeniopsis notabilis with $A$. regulus. On the basis of a careful study of the external characters and the male genitalia, I am here reestablishing the name $A$. notabilis as the type species of the genus. The species differs from regulus in having more distinct clypeal wrinkles, pronotum lacking a marginal line and abdominal sternites nearly smooth, without fluting.

\section{Ataeniopsis pusillus (Burmeister, 1877), comb. n.}

(Figs 2, 9, 13)
Euparia pusilla Burmeister, 1877: 410.

Ataenius pusillus: Schmidt 1908: 94; 1922: 434; Dellacasa 1988: 280 (catalogue).

Type. Described from Argentina, location unknown.

Specimens examined (576). Argentina - 2 ex. det. A. Schmidt (ZMHB); Prov. Corrientes, $10 \mathrm{~km} \mathrm{E} \mathrm{Corrientes,}$ 11.XII.1990, S.\& J. Peck; Prov. Formosa, Ingiero Guillermo, Nueva Juarez, XII.1953, coll. Martinez; 50 km NW Clorinda P.N. Rio Pilcomayo, 17.XII.1990, S.\& J. Peck (CMN); Gran Guardica; Ciudad (MHNG, ZMHB); Prov. Tucumán, Dpto Capital, Puente Rio Sali, XI.1950, coll. Martinez (identified by Chalumeau as $A$. haroldi); Prov. San Luis, $18 \mathrm{~km} \mathrm{~S} \mathrm{Arizona} 250$ m, 18-23.I.1980, H.\& A. Howden (CMN); Prov. Chaco, Resistencia, 12.XI.1950, A. Willink (FMLT), 23.XII.1965, leg. Mahunka (HNHM); Charata, III.1993, leg. Di Torio (JSC); Prov. Santa Fe, Reconquista, 23.XII.1965, leg. Mahunka (HNHM); Prov. Misiones, 30 km S San Juan Bautista (ZMHB); Neembucu, $5 \mathrm{~km} \mathrm{~N}$ Pilar (HNHM); Prov. Jardin America, Salto Tabay, 22.XI,1990, S.\& J. Peck (CMN); Prov. Cordoba, Dpto Cruz del Eje, 1977, coll. Martinez (CMN); Prov. Entre Rios, Colon, 29.XII.1991, coll. Archangelsky (WWC); Prov. Salta, El Rey Nat. Park, 900 m, 1-10.XII.1987, S.\& J. Peck (CMN); Prov. Santiago del Estero, Ojo de Agua, 20.II.1980, H.\& A. Howden (CMN). Bolivia - Santa Cruz, 3.7 km SSE Buena Vista Hotel Fauna \& Flora $430 \mathrm{~m}, 22-26 . X .2000$, M.C. Thomas (FSCA). Paraguay - Paraguari $35 \mathrm{~km} \mathrm{~W}$ Carapegua (ZSM); Caacupa, 15-19.XI.1990, S.\& J. Peck (CMN). Uruguay Tacuarembo, Pare Batile (USNM).

Diagnostic characters. Length $3.5-3.8 \mathrm{~mm}$. Colour of body (Fig. 2) piceous, legs lighter Clypeal emargination moderate, edge on each side of emargination obtuse, even slightly rounded, lacking denticles; surface of head microreticulate, usually roughly wrinkled from anterior margin to vertex, occipital area with band of close punctures. Pronotum slightly transverse, base distinctly margined by smooth line; pronotal punctures fine to moderate in size, on disc irregularly spaced becoming closer toward sides and lateral margin, separated by about one diameter. Elytra parallel, about 2.5 times as long as pronotum, striae distinctly impressed with fine punctures; discal intervals flat, shiny, surface punctures minute to fine, scattered, sometimes invisible. Prosternum and inner surface of profemur with close whitish hair; mesosternum rugosely shagreened, metasternal midline shallow; abdominal sternites finely fluted along sutures, surface smooth, impunctate, slightly swollen at extreme sides, pygidium polished, convex, in some specimens disc with trace of longitudinal carina and few minute punctures. Meso- and metafemur fusiform, with fine scattered punctures; metatibia slender, apex without accessory spine; basal tarsomere of metatarsus a trifle longer than following three tarsomeres combined.

Male. Abdominal sternite 3 longer than sternite 4; sternite 5 two thirds length of sternite 4 . Genitalia as in Fig. 9.

Female. Sternites 2-4 equal in length, sternite 5 slightly shorter than sternite 4 .

Remarks. Ataeniopsis pusillus as now defined is one of the commonest members of the genus. The shape of clypeus and sculpture of the head as well as its southern distribution in South America (Fig. 13) easily distinguish 
this species. It seems to be closest to $A$. parallelus, but differs from that species by the characters given in the key. Specimens were collected in the area of suburban grassland, riverine forest and tropical transition forest, attracted to UV light traps in a great number of individuals.

\section{Ataeniopsis parallelus (Petrovitz, 1961)}

(Figs 10, 12)

Ataenius parallelus Petrovitz, 1961: 148.- Dellacasa, 1988: 278 (catalogue).

Ataenius (Ataeniopsis) parallelus: Chalumeau, 1992: 196 (nota).

Type material examined. Holotype (MHNG) and paratypes (10) labelled "Amazonas, Nhamundi, 1959, leg. Cappelletto", “Ataenius parallelus Petrovitz”, in ISEA, MHNG, ZMHB.

Diagnostic characters. Length $2.8-3.0 \mathrm{~mm}$. Body moderately shining, piceous black, legs reddish brown. Clypeal emargination shallow, denticles on each side of emargination fine but distinct; surface of head subopaque, finely, roughly sculptured, frontal suture marked by line, vertex with band of close punctures. Pronotum slightly transverse, basal marginal line fine with minute crenations; pronotal punctures mixed minute and fine, very close, everywhere distributed. Elytra parallel, about 2.5 times as long as pronotum, striae deep with slightly crenating punctures; discal intervals slightly convex, surface punctures very minute. Prosternum and inner surface of profemur with short hair; metasternal midline shallow; abdominal sternites finely fluted along sutures, surface slightly uneven at extreme sides; pygidium with 3-4 fine punctures along median carina, apical lip convex. Mesoand metafemur fusiform with fine scattered punctures, metafemur a trifle longer than mesofemur; metatibia slender, apex without accessory spine; basal tarsomere of metatarsus longer than following three tarsomeres combined.

Male. Abdominal sternite 3 twice as long as sternites 4 and 5; sternites 4 and 5 equal in length. Genitalia as in Fig. 10 .

Female. Abdominal sternite 3 slightly longer than sternites 4 and 5 ; sternites 4 and 5 equal in length.

Remarks. The small size and very close punctures on the pronotum easily distinguish $A$. parallelus from related species. No additional specimens were found in the material examined and nothing is known about its biology.

\section{Ataeniopsis vinacoensis sp. $\mathbf{n}$.}

(Figs 11, 13)

Type material. Holotype male, Argentina, Prov. Salta, Viñaco, $15 \mathrm{~km} \mathrm{~S} \mathrm{El} \mathrm{Carril,} \mathrm{12.II.1982,} \mathrm{H. \&} \mathrm{A.} \mathrm{Howden,} \mathrm{in}$ CMN (HAHC). Paratypes (10): 1 - same data as holotype; 4 Prov. Cordoba, 4 km NE Cruz del Eje, 20.II.1982, H.\& A. Howden; 5 - Formosa, Ingiero Guillermo Nueva Juarez. XII.1953, A. Martinez. Paratypes are in: CMN (HAHC), ISEA.

Description. Length $4.2-4.5 \mathrm{~mm}$. Colour dark red to black, legs reddish brown. Head markedly gibbose at middle, clypeus with shallow emargination and sharp denticles on each side; surface of head shiny, finely wrin- kled to vertex, frontal suture not indicated, punctures on vertex very fine, variable in density, usually irregularly spaced. Pronotum subquadrate, basal marginal line distinct, basal edge smooth; pronotal punctures mixed minute, fine and moderate, usually fine along anterior margin then larger towards base and sides, irregularly spaced, shallow at anterior angle and vanishing at posterior angle. Elytra parallel, slender, about 3 times as long as pronotum, striae distinctly impressed with fine contiguous punctures slightly crenating inner margins of intervals; discal intervals slightly convex, shiny, surface punctures very minute scattered or lacking. Prosternum and inner surface of profemur with rather long hair; metasternal midline impressed; abdominal sternites with moderate fluting along sutures, slightly arcuate, surface smooth, impunctate; pygidium polished, slightly curved ventrally, apical lip convex. Meso- and metafemur equal in length, fusiform with fine scattered punctures; metatibia slender, apex without accessory spine; basal tarsomere of metatarsus longer than following three tarsomeres combined. Epipharyngeal structures similar to those of $A$. haroldi (Fig. 4).

Male. Abdominal sternite 3 longer than sternite 4; sternite 5 half length of sternite 4 . Genitalia as in Fig. 11.

Female. Abdominal sternites 2-4 equal in length, sternite 5 half length of sternite 4 .

Affinity. Ataeniopsis vinacoensis sp. n. is most closely related to $A$. haroldi, both species occur sympatrically (Figs 12,13). It differs from haroldi by its narrower and more slender elytra and arcuate abdominal sternites. The male genitalia also differ in shape (Figs 6, 11).

Etymology. Derived from the type locality "Viñaco".

\section{Ataeniopsis carupanoi sp. n.}

(Figs 13, 14)

Type material. Holotype male, Venezuela, Carúpano, VIII.1971, J. Maldonado, in USNM. Paratypes (2), same data as holotype, in ISEA, USNM.

Description. Length 3.2-3.6 mm. Body slender, reddish black, legs somewhat lighter. Clypeal emargination shallow, denticles on each side of emargination fine, surface of head shiny, distinctly wrinkled from anterior margin to vertex, punctures on vertex fine, not close, irregularly spaced. Pronotum subquadrate, basal marginal line very fine, basal edge minutely crenate, crenations visible when pronotum viewed from behind; pronotal punctures moderate in size, slightly irregularly distributed, separated by 2-3 diameters, lacking along lateral margin. Elytra narrow, parallel, about 2.5 times as long as pronotum, striae shallow with fine punctures; discal intervals flat, shiny, surface punctures invisible. Prosternum and inner side of profemur with rather long pale hair; metasternal midline shallowly impressed; abdominal sternites with inconspicuous fluting, almost smooth along sutures, surface smooth, impunctate; pygidium polished, apical lip convex. Meso- and metafemur fusiform with fine scattered punctures, metafemur a trifle longer than mesofemur; metatibia slender, apex without accessory spine; basal tarsomere of 
metatarsus longer than following three tarsomeres combined. Epipharyngeal structures similar to those of $A$. haroldi (Fig. 4).

Male. Abdominal sternite 3 longer than sternite 4, sternite 5 half length of sternite 4. Genitalia as in Fig. 14.

Female. Abdominal sternite 3 only slightly longer than sternite 4 ; sternite 5 half length of sternite 4 .

Affinity. The species is most closely related to $A$. regulus, but surface of the head is not so distinctly shagreened as in $A$. regulus, the pronotal lateral area is almost impunctate and the abdominal sternites are inconspicuously fluted

Etymology. Derived from the type locality "Carúpano".

\section{Ataeniopsis jaltipani sp. $\mathbf{n}$.}

(Figs 12, 18)

Type material. Holotype male, Mexico, Veracruz, $3.5 \mathrm{~km} \mathrm{E}$ Jaltipan, Rte. 180 at UV light, 150 m, 6.V.1977, Mexican Exp. 77, J.S. Ashe \& H.E. Frania \& D. Shpeley, in USNM. Paratypes (23): 8 - same data as holotype; 1 - Veracruz, El Palmes, $16 \mathrm{~km}$ W Tetz Tapa, 600 ft, 9.VI.1948, F. Werner \& W. Nutting; 2 Veracruz, Coatzacoalcos, 26.VI.1971; 3 - Veracruz, Palma Sola Reyes, VII. 1972, G. Halfter (Coll. Martinez); 9 - El Cora, Tepic, A. Lüdecke. Paratypes are in: CMN, ISEA, USNM, ZMHB.

Description. Length $3.2-3.8 \mathrm{~mm}$. Body parallel, colour reddish black to black, legs usually lighter than bottom surface. Clypeus almost truncate anteriorly or emargination very shallow, denticles on each side of emargination acutely triangular, surface of head finely microreticulate, shining, frontal suture not indicated, clypeal wrinkles fine, punctures on vertex variable in density, not close, usually irregularly spaced. Pronotum slightly transverse, basal marginal line absent, basal edge almost smooth, pronotal punctures mixed minute and fine, the latter generally separated by more than one diameter, shallow at anterior angles, scattered on sides, minute punctures visible along lateral and anterior margin. Elytra parallel, about 3 times as long as pronotum, striae impressed with fine punctures; discal intervals flat, shiny, surface punctures indistinct. Prosternum and inner surface of profemur with moderate to long hair; metasternal midline shallow; abdominal sternites arcuate without fluting, almost smooth along sutures, surface smooth, impunctate; pygidium polished, strongly shining, slightly curved ventrally, apical lip convex. Meso- and metafemur fusiform with fine scattered punctures; metafemur slightly longer than mesofemur; metatibia slender, apex without accessory spine; basal tarsomere of metatarsus subequal in length to following three tarsomeres combined. Epipharyngeal structures similar to those of $A$. haroldi (Fig. 4).

Male. Abdominal sternite 3 slightly longer than sternite 4; sternites 4, 5 equal in length. Genitalia as in Fig. 15.

Female. Abdominal sternites 3 and 4 equal in length; each slightly longer than sternite 5 .

Affinity. Ataeniopsis jaltipani $\mathrm{sp} . \mathrm{n}$. is closely related to $A$. duncani, but may be easily distinguished by the lack of basal marginal line of the pronotum and nearly smooth abdominal sutures. The present state of knowledge indi- cates that these species are allopatrically distributed (Fig. 12).

Etymology. Derived from the type locality "Jaltipan".

Ataeniopsis armasi (Chalumeau, 1982)

(Figs 12, 15)

Ataenius (Ataeniopsis) armasi Chalumeau, 1982: 321-323, Fig. 1, 4.- Dellacasa 1988: 352 (catalogue).

Type material. Holotype male, labelled "Puerto Rico, La Parguera, 28.VII.1969, H. \& A. Howden", in CMN.

Other specimens examined (18). West Indies - Dominican Rep., Prov. Monte Cristi, $4.8 \mathrm{~km} \mathrm{~N}$ Villa Elisa, 31.V.1994, M.C.Thomas; 31.V.1994, R. Turnbow (FSCA, ISEA). Puerto Rico, La Parguera, 28.VII.1969, H.\& A. Howden (ISEA).

Diagnostic characters. Length $3.3-3.8 \mathrm{~mm}$. Colour reddish black to black, legs somewhat lighter. Clypeal emargination shallow, denticles on each side of emargination fine but distinct; surface of head shiny, finely wrinkled from anterior margin to vertex, punctures on vertex variable in density, usually irregularly spaced. Pronotum slightly transverse with basal marginal line, basal edge smooth; surface punctures moderate in size, usually finer along anterior margin and larger towards base and sides, irregularly spaced, fine and shallow at anterior angle and missing at posterior angle. Elytra parallel, about 3 times as long as pronotum, striae impressed with contiguous, crenating punctures; discal intervals slightly convex, surface punctures very minute. Prosternum and inner side of profemur with rather long hair; metasternal midline weakly marked; abdominal sternites $2-3$ without fluting, sternites 4-5 finely fluted along sutures, surface smooth, impunctate; pygidium polished, apical lip convex. Mesoand metafemur equal in length, both with fine scattered punctures; metatibia slender, apex without accessory spine; basal tarsomere of metatarsus longer than following three tarsomeres combined.

Male. Abdominal sternite 3 longer than sternite 4; sternite 5 half length of sternite 4 . Genitalia as in Fig. 15

Female. Abdominal sternites 2-4 equal in length, sternite 5 about two thirds length of sternite 4 .

Remarks. The West Indian Ataeniopsis armasi is intermediate between the Mesoamerican species $A$. duncani and $A$. jaltipani $\mathrm{sp}$. n. It differs from the former species by its less heavily punctate pronotum, from the latter by partially fluted abdominal sternites and presence of a pronotal basal margin. Chalumeau (1982) recorded this species from Puerto Rico, Dominican Rep., Haiti and Guadeloupe. The specimens were collected to black light traps.

\section{Ataeniopsis parkeri (Cartwright, 1974)}

(Figs 13, 16)

Ataenius parkeri Cartwright, 1974: 21-23, Fig. 3. - Dellacasa 1988: 343. (catalogue).

Ataenius (Ataeniopsis) parkeri: Chalumeau 1992: 196 (nota).

Type material. Holotype male, labelled "Douglas Arizona, 10-16.VII.1968, J.H. Russel”, No 71734 USNM. Paratypes (10), labelled “Arizona, Nogales, 17.VIII.1947, H. Parker", in CMN. 

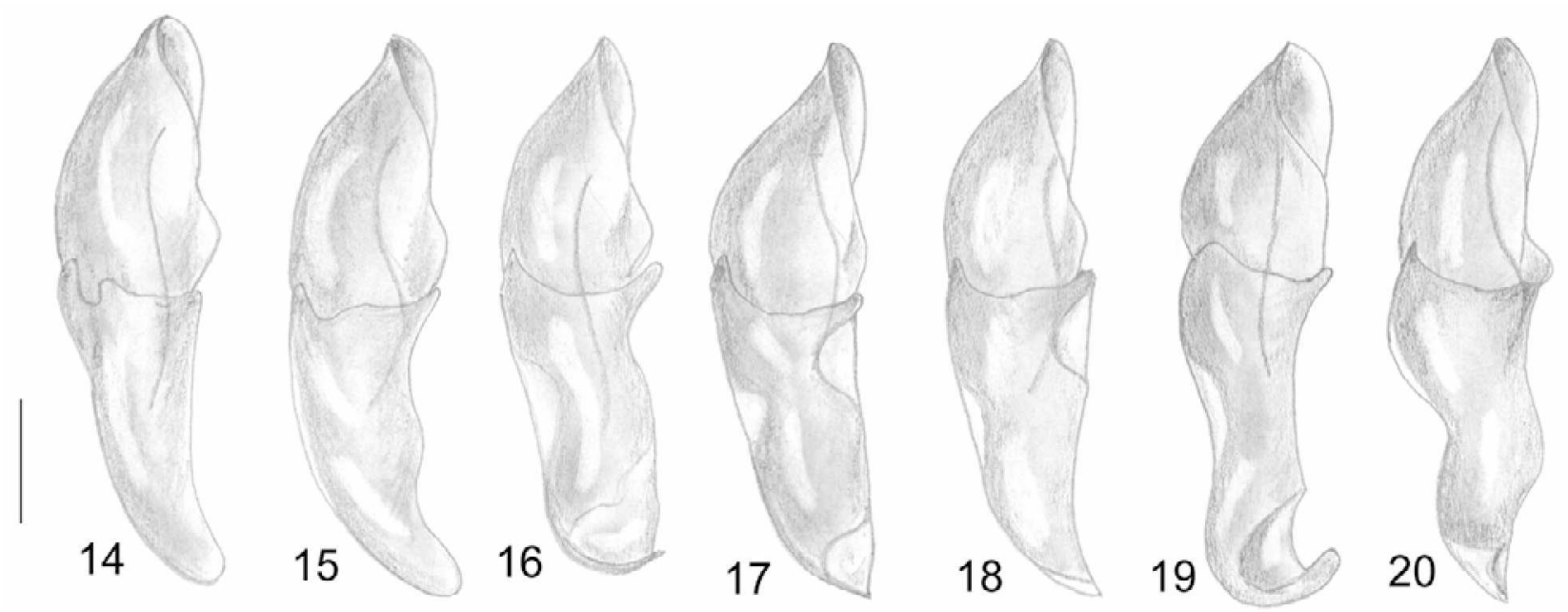

Figs 14-20. Aedeagi in lateral view. 14 - Ataeniopsis carupanoi sp. n.; 15 - A. armasi; 16 - A. parkeri; $17-$ A. duncani; $18-$ A. jaltipani sp. n.; $19-$ A. migopygus; $20-$ A. figurator. Scale line: $0.25 \mathrm{~mm}$.

Other specimens examined (15). USA - Arizona, Tempe, 4-5.IX.1962; Green Valley, Pine Co., VIII.1971. R. Lenosy. ISEA Mexico - Sinaloa, Culiacan, 16.VII.1963, P.J. Spangler (ISEA), 13.XI. 1982, W.H. Cross (UM); Jalisco, $10 \mathrm{mi} \mathrm{N}$ Chapala, 31.VII.1969, P.J. Spangler; Sonora, Hermosillo, 19-20.IX.1952, B. Malkin (ISEA, USNM); Sonora, San Nicolas, rd. to La Angostura, $1400 \mathrm{~m}, 11$.VIII.1982, K.E. Ball \& S. McCleve; $19.8 \mathrm{~km}$ W Santa Ana, Sonoran desert $710 \mathrm{~m}$, 23.VIII.1982, Mex. Exp. 1982 (CMN, ISEA).

Diagnostic characters. Length $4.0-4.3 \mathrm{~mm}$. Colour castaneous to reddish black, legs usually lighter. Clypeal emargination shallow, denticles on each side of emargination triangular, distinct, surface of head shiny, frontal suture not indicated, clypeal wrinkles fine, vertex with band of fine close punctures. Pronotum slightly transverse, side broadly, continuously rounded to base, basal marginal line distinct, smooth; pronotal punctures moderate in size, widely scattered and irregularly spaced Elytra parallel, about 3 times as long as pronotum, striae shallow with fine punctures; discal intervals flat, shiny, surface punctures very minute. Prosternum and inner side of profemur with short hair; metasternal midline weakly marked; abdominal sternites with fine fluting along sutures, surface smooth, impunctate; pygidium curved ventrally, smooth, apical lip convex. Meso- and metafemur equal in length, fusiform with fine scattered punctures; metatibia slender, apex without accessory spine; basal tarsomere of metatarsus a trifle longer than following three tarsomeres combined.

Male. Abdominal sternite 3 slightly longer than sternites 4 and 5 ; sternite 5 half length of sternite 4 . Genitalia as in Fig. 16.

Female. Abdominal sternites 2-4 equal in length, sternite 5 half length of sternite 4 .

Remarks. This species is very close to $A$. duncani but it is usually lighter in colour than that species, the pronotum is also less heavily punctate and the pronotal posterior angle is very smoothly arcuate. Both species occur sympatrically in the Sonoran province (Fig. 13). Cartwright (1974, Fig. 3) recorded A. parkeri from Arizona,
Texas and Mexico (Sonora, Hermosillo). The specimens were taken by light traps on oak grassland.

\section{Ataeniopsis duncani (Cartwright, 1974)}

(Figs 13, 17)

Ataenius duncani Cartwright, 1974: 24-26, Fig. 2. - Dellacasa 1988: 343 (catalogue).

Ataenius (Ataeniopsis) duncani: Chalumeau 1992: 196 (nota).

Type material. Holotype male, labelled "Arizona Tucson, 11.VIII.1968, K. Stephan", No 71736 USNM. Paratypes (3) labelled: 1 - "Arizona, Phoenix"; 1 - "Arizona, Wilcox Playa, Cochise Co., 24.VIII.1970, K. Stephan"; 1 - "New Mexico, Peloncillo Mts, 5.VII.1956, H.\& A. Howden", in CMN

Other specimens examined (51). USA - Arizona, Tempe, 2-3.IX.1962; Casa Grande, 5.VIII.1924, B. Schroeder (ZMHB); Mexico - Durango (no additional collecting data) (ZMHB); Durango, $49 \mathrm{~km} \mathrm{~N}$ Durango City, $1980 \mathrm{~m}$, 28.VII.1993, K.E. Ball (ISEA); Guanajuato, $14 \mathrm{mi} \mathrm{NE}, 7700 \mathrm{ft}, 16 . \mathrm{VIII} .1974$, O'Brien \& Marshall (UMB); Sonora near Hermosillo, 17.VII.1978, Helava \& Kukal (CMN, ISEA); Coamuila, Parras de la Fuente, Rincon del Montero, 1.VII.1971, B.K. Dozier (FSCA); Baja California Sur, $20 \mathrm{~km} \mathrm{~S} \mathrm{La} \mathrm{Paz,} \mathrm{27.VIII.1994,} \mathrm{R.}$ Morris ; 2 km S Mulegé, 14.VIII.1992, H.\& A. Howden (CMN, FSCA).

Diagnostic characters. Length $3.5-4.1 \mathrm{~mm}$. Elongate, parallel, piceous, legs reddish. Clypeal emargination shallow, edge on each side sharply triangularly dentate; surface of head finely rugulose up to median convexity, frontal suture not indicated, vertex with band of close punctures. Pronotum slightly transverse, basal marginal line distinct, smooth; pronotal punctures coarse to moderate in size, deep, usually evenly distributed but irregularly spaced, missing along lateral margin. Elytra parallel, about 3 times as long as pronotum, striae shallow with fine crenating punctures; discal intervals flat, shiny, surface punctures very minute. Prosternum and inner side of profemur with moderately long hair; metasternal midline impressed; abdominal sternites with fine fluting along sutures, surface smooth, impunctate; pygidium polished, 
apical lip convex. Meso- and metafemur equal in length, fusiform with fine scattered punctures; metatibia slender, apex without accessory spine; basal tarsomere of metatarsus longer than following three tarsomeres combined.

In both sexes, abdominal sternite 3 longer than sternites 4 and 5; sternites 4, 5 equal in length. In male, pygidium longer and more convex than in female, genitalia as in Fig. 17.

Remarks. The species is most close to $A$. parkeri (see Remarks under that species). Distributed in Sonoran province (Fig. 13), recorded by Cartwright (1974, Fig. 2) from Arizona, California, Colorado, Kansas, New Mexico and Texas. In Mexico found for the first time. The specimens were taken by light traps on Acacia grassland.

\section{Ataeniopsis rugopygus (Cartwright, 1974)}

(Figs 12, 19)

Ataenius rugopygus Cartwright, 1974: 23-24, Fig. 4. Dellacasa 1988: 343 (catalogue).

Ataenius (Ataeniopsis) rugopygus: Chalumeau 1992: 196 (nota).

Type material. Holotype male, labelled "Texas, Davis Mts, 27.V.1935, J.N. Knull”, No 71735 USNM.

Other specimens examined (10). Mexico - Chihuahua, 20 mi S Juarez, 19.VII.1952, R.B. Selander; Durango, Cerro Gordo, 28.VI.1964, P.J. Spangler (ISEA, USNM); Durango, 27 mi S Ceballos, $900 \mathrm{~m}, 10 . \mathrm{V} .1982$, M.A.Ivie (ISEA, UMB).

Diagnostic characters. Length $4.0-4.3 \mathrm{~mm}$. Elongate, parallel, strongly shiny, piceous, legs usually lighter. Clypeal emargination wide, edge sharply triangularly dentate on each side; surface of head roughly transversely wrinkled to vertex, wrinkles usually broken into short segments, vertex with band of close punctures. Pronotum slightly transverse, basal marginal line distinct, smooth; surface throughout with mixed minute and moderate punctures, close and quite evenly distributed. Elytra parallel, about 3 times as long as pronotum, striae moderately deep with fine punctures crenating both sides of weakly convex intervals. Prosternum and inner surface of profemur hairy; metasternal midline shallow; abdominal sternites with fine fluting along sutures, surface smooth, impunctate; pygidium without distinct punctures but irregularly swollen, shiny, slightly curved ventrally, apical lip convex. Meso- and metafemur equal in length, with fine scattered punctures; metatibia slender, apex slightly expanded without accessory spine; basal tarsomere of metatarsus subequal in length to following three tarsomeres combined.

Male. Abdominal sternite 3 longer than sternites 4 and 5; sternite 5 twice length of sternite 4 . Genitalia as in Fig. 19.

Female. Abdominal sternite 3 slightly longer than sternites 4, and 5; sternites 4 and 5 equal in length.

Remarks. Ataeniopsis rugopygus may be easily recognized by the characters given in the key. Some specimens show uneven pygidial surface, and some have the pygidium with very little other sculpture. The species occurs in the Sonoran province (Fig. 12), recorded by Cartwright (1974, Fig. 4) from Arizona, Colorado, Iowa,
New Mexico and Texas. In Mexico found for the first time.

\section{Ataeniopsis figurator (Harold, 1874)}

(Fig. 20)

Ataenius figurator Harold, 1874: 24. - Bates 1887: 99 (non Harold, 1874); Horn 1887: 79-80; Schmidt 1922: 435; Chapin 1940: 15-16 (as synonym of A. haroldi); Woodruff 1973: 118; Cartwright 1964: 103; 1974: 19-21, Fig. 5; Dellacasa 1988: 129 (catalogue) (as synonym of $A$. haroldi); Deloya 1994: 48 (not Harold, 1874).

Ataenius (Ataeniopsis) figurator: Chalumeau 1992: 196 (nota).

Type material. Lectotype "Louisiana" designated by Cartwright (1973), in MNHN.

Other specimens examined (15). USA - Clemson S.C. 17. VII.1934, O.L. Cartwright (HNHM, ISEA); Durham N.C., Duke forest, VIII.1970, S. Hughes-Schrader (ISEA).

Diagnostic characters. Length $3.3-4.2 \mathrm{~mm}$. Body strongly shiny, black, not quite parallel. Clypeal margin with only barest trace of suspicion of angulation or tooth on each side of broad and shallow emargination, surface of head finely wrinkled up to median convexity, vertex with band of moderate close punctures separated by less than one diameter. Pronotum slightly transverse, basal marginal line distinct, punctures moderately coarse, variable, usually finer along anterior margin and larger towards base and sides, mixed fine and moderate, irregularly spaced, fine and shallow at anterior angle and along lateral margin. Elytra not quite parallel, about 2.5 times as long as pronotum, striae moderately fine, finely crenatepunctate, discal intervals weakly convex, surface punctures fine and scattered. Prosternum and inner surface of profemur with short hair; metasternal midline weakly impressed; abdominal sternites finely fluted along sutures, surface slightly roughened at extreme sides, pygidium polished, smooth, apical lip convex. Meso- and metafemur equal in length with fine scattered punctures; metatibia slender, apex without accessory spine; basal tarsomere of metatarsus noticeably longer than following three tarsomeres combined.

In both sexes, abdominal sternite 3 longer than sternites 4 and 5; sternite 5 half length of sternite 4 . In male, disc of pygidium longer and more convex than in female, genitalia as in Fig. 20.

Remarks. Ataeniopsis figurator was synonymized with A. haroldi by Chapin (1940) who cited it from Argentina, Mexico, West Indies and North America. This species, widely distributed in the middle and eastern United States (see Cartwright 1974, Fig. 5), is apparently restricted to that area and does not occur in Mexico. The distribution data given by Deloya (1994) is that of at least three other species.

Ataeniopsis saxatilis (Cartwright, 1944), comb. n.

Ataenius saxatilis Cartwright, 1944: 29. - 1974: 18-19, Fig. 4.

Ataenius saxatialis (sic!): Dellacasa 1988: 280 (catalogue). 
Type material. Holotype male, labelled "Bogg's Rock, Liberty South Carolina", No 56942 USNM. Paratypes (3), labelled "Liberty S.C. 10.VII.1940, O.L Cartwright"; "Columbus Ga. 6.VII.1941, O.L. Cartwright"; "Buck's Forest N.C., 22.VII.1941, O.L. Cartwright", in HNHM.

Diagnostic characters. Length $3.5-4.6 \mathrm{~mm}$. Oblong, convex, strongly shiny, piceous, sides of pronotum and legs dark castaneous. Head convex, clypeus broadly rounded on each side of shallow median emargination, without trace of denticles; surface of head feebly wrinkled and very finely punctate over anterior third, front with rather wide band of close, moderate punctures usually irregularly spaced. Pronotum slightly transverse, basal marginal line fine, surface punctures mixed minute and moderately coarse, sparse and irregularly spaced. Elytra arcuate, widest slightly beyond middle, about 2.5 times as long as pronotum, with minute humeral denticle; striae shallow with fine punctures; discal intervals flat, highly polished, surface punctures very minute. Prosternum and inner surface of profemur with short hair; metasternal midline shallow; abdominal sternites very finely fluted along sutures, surface polished smooth, pygidium polished, apical lip convex. Meso- and metafemur equal in length, fusiform with fine scattered punctures; apex of metatibia expanded without accessory spine; basal tarsomere of metatarsus equal in length to following three tarsomeres combined.

Male. Abdominal sternite 3 longer than sternites 4 and 5; sternite 5 about two thirds length of sternite 4 , pygidium longer than in female. Genitalia similar in shape to those of $A$. figurator (Fig. 20).

Female. Abdominal sternites 2-4 equal in length; sternite 5 slightly shorter than sternite 4 .

Remarks. Ataenius saxatilis is most close to A. figurator but it is more robust than $A$. figurator and than all other species in the genus, and differs in a general shape. Apart from the type series, no additional specimens were found in the material examined. This species was reported by Cartwright (1974, Fig. 4) from Georgia and North Carolina, specimens were collected from the sand and soil around weathered areas of granite and gneissic rocks.

Ataeniopsis edistoi (Cartwright, 1974), comb. n.

Ataenius edistoi Cartwright, 1974: 17-18, Fig. 2. - Dellacasa 1988: 343 (catalogue).

Type material. Holotype female, labelled "South Carolina Colleton Co. 5 mi E Canadys, St. Hwy 61 along Edisto River, 19-22.V.1968, O.L. Cartwright", No 71733 USNM.

Diagnostic characters of female. Length $3.9 \mathrm{~mm}$. Elongate-oblong, shiny black with anterior margin of clypeus, anterior margin of pronotum and legs reddish. Clypeal emargination wide and shallow, edge on each side rounded, with no trace of denticles, surface of head wrinkled over anterior half, upper half closely finely punctate, vertex with narrow band of fine punctures. Pronotum subquadrate, basal marginal line distinct; surface with evenly distributed, close, mixed very fine and moderate punctures generally separated by about one diameter, more numerous at anterior angle. Elytra not quite parallel, about 2.5 times as long as pronotum, humeri finely dentate; striae moderately crenate-punctate, discal intervals flat, shiny, surface punctures very minute. Prosternum and inner surface of profemur with moderately long hair; metasternal midline long, not deeply impressed, disc finely punctate; abdominal sternites finely fluted along sutures, surface punctures fine, scattered, sternites 2-4 equal in length, sternite 5 about three quarters length of sternite 4; pygidium with fine, rather close punctures along median carina. Meso- and metafemur equal in length with fine scattered punctures; apex of metatibia expanded without accessory spine; basal tarsomere of metatarsus a trifle longer than following three tarsomeres combined.

Remarks. Ataeniopsis edistoi is closely related to $A$. figurator and $A$. saxatilis and similar in general appearance, being slightly broader in shape than figurator and not quite as broad as saxatilis. However, the lack of male specimens in the material examined (except a single available, badly damaged individual) does not allow a comparison of male genitalia. A. edisto $i$ is hitherto known from a small number of specimens collected exclusively in South Carolina (Cartwright 1974, Fig. 2) under surface litter on sandy ground along the roadsides.

ACKNOWLEDGEMENTS. Assistance from all sources, personal as well as institutional is gratefully acknowledged. I wish to express my cordial thanks to: D. Ahrens (Dresden), $\mathrm{H}$. Howden and F. Génier (Ottawa), H. \& A. Howden Collection (Ottawa), O. Merkl (Budapest), A. Teràn (Tucumán), B. Merz, G. Cuccodoro, I. Löbl (Geneva), C. Costa (São Paulo), K. Desender (Stockholm), P. Skelley (Gainesville), P. Lago (Mississippi), N. Adams and G. House (Washington DC), W. Warner (Arizona), H. Wendt and J. Schulze (Berlin). I am especially indebted to H. Howden (Ottawa) for comments on a series of manuscripts dealing with the New World Aphodiinae.

Funding for this study on the Neotropical fauna came from the Ministry of Science in Poland, Grant KBN No 6PO4C 08922.

\section{REFERENCES}

Balthasar V. 1947: De novis generis Ataenius Har. speciebus. Acta Entomol. Mus. Nat. Prag. 25: 49-54.

Bates H.-W. 1887: Col.: Lam. (Copridae, Aphodiidae, Orphnidae, Hybosoridae, Geotrupidae, Trogidae, Aclopidae, Chasmatopteridae, Melolonthidae). Biol. Centr.-Am. Insecta 2: 26-160.

BurmeIsTER H.C.C. 1877: Die Argentinischen Aphodiaden. Stettin. Entomol. Ztg. 38: 401-414.

CARTWRight O.L. 1944: New Scarabaeidae from United States. Ann. Entomol. Soc. Am. 37: 28-36.

CARTwRIGHT O.L. 1964: Lectotype designations and new synonymy in the genus Ataenius. The Coleopterist's Bulletin 18: 101-104.

CARTwRIGHT O.L. 1973: Additional lectotype designations in the Aphodiinae. The Coleopterist's Bulletin 27: 41-43.

CARTwright O.L. 1974: Ataenius, Aphotaenius and Pseudataenius of the United States and Canada. Smithson. Contr. Zool. 154: 1-106.

Chalumeau F. 1982: Contribution à l'étude des Scarabaeoidea des Antilles (III). Nouv. Revue Entomol. 12: 321-345.

Chalumeau F. 1992: Eupariini du Nouveau monde: un mise au point (Coleoptera: Scarabaeidae) (1re partie). Nouv. Revue Entomol. 9: 189-206. 
CHAPIN E.A. 1940: A revision of the West Indian beetles of the Scarabaeid subfamily Aphodiinae. Proc. U. S. Nat. Mus. 89 $1-41$.

Dellacasa M. 1988: Contribution to a world-wide catalogue of Aegialiidae, Aphodiidae, Aulonocnemidae, Termitotrogidae (Coleoptera: Scarabaeoidea). Mem. Soc. Entomol. Ital. 66: 3-455.

Deloya C. 1994: Distribucion del genero Ataenius Harold, 1867 en Mexico (Col. Scarab. Aphodiinae, Eupariini). Acta Zool. Mex. 61: 43-56.

Goloboff P. A. 1993. NONA, version 2.0. Published by the author. INSUE Fundación e Instituto Miguel Lillo, Tucumán, Argentina.

Harold E. 1867: Diagnosen neuer Coprophagen. Coleopter. Hefte 1: 76-83.

Harold E. 1874: Ueber die Ataenius-Arten mit gezahntem Kopfschilde. Coleopter. Hefte 12: 15-25.

HorN G.H. 1887: A monograph of the Aphodiini inhabiting the United States. Trans. Am. Entomol. Soc. 14: 1-110.

Le peletier de Saint-Fargeau A. L. M. \& Audinet-Serville J. G. A. 1828: Scarabé. Encyclopédie Méthodique. Vol. 10. Agasse, Paris, pp. 346-382.

NiXON K. C. 1999. WINCLADA (beta) version 0.9.99. Published by the author. Ithaca, New York.

Petrovitz. R. 1961: Neue und bemerkenswerte Aphodiinae aus dem Museo entomologico del Pontificio Instituto Missioni estere, Monza. Boll. Soc. Entomol. Ital. 91: 144-149.

Petrovitz R. 1972: Neue Laparostikte Scarabaeiden aus der orientalischen und neotropischen Region. Mem. Soc. Entomol. Ital. 51: 161-168.

Petrovitz R. 1973: Neue Aphodiinae, Hybosorinae und Acanthocerinae aus der Neotropischen Region. Studia Entomol. 16: 141-202.

SchмiDT A. 1908: Zusammenstellung der bis 1906 beschriebenen Aphodiinen (1907-1908). Dt. Entomol. Z. (Beil.) $1-141$.

Schmid A. 1922: Coleoptera, Aphodiinae. Das Tierreich. Vol. 45. Walter de Gruyter \& Co., Berlin und Leipzig, 614 pp.

SteBnicka Z. 1999a: Neotropical Eupariini: New and little known genera and species (Coleoptera: Scarabaeoidea: Aphodiinae). Revue Suisse Zool. 106: 285-300.
Stebnicka Z. 1999b: Lomanoxia Martinez, 1951, and a new tribe Lomanoxiini with notes on comparative morphology (Coleoptera: Scarabaeoidea: Aphodiinae). Acta Zool. Cracoviensia 42: 279-286.

SteBnICKA Z. 1999c: A new genus and species of termitophilous Eupariini from Ecuador with checklist of the Neotropical genera (Coleoptera: Scarabaeidae: Aphodiinae). Acta Zool. Cracoviensia 42: 289-295.

SteBnicka Z. 2000: The genus Passaliolla Balthasar, 1945 in Central and South America (Coleoptera: Scarabaeidae: Aphodiinae: Eupariini). Acta Zool. Cracoviensia 43: 233-239.

STeBnicka Z. 2001a: A revision of the Neotropical species of Saprosites Redtenbacher, 1858 (Insecta: Coleoptera: Scarabaeidae: Aphodiinae: Eupariini). Entomol. Abhandlungen 59: 221-242.

SteBnicka Z. 2001b. The New World species of Ataenius Harold, 1867. I. Revision of the A. crenator-group, A. nugatorgroup and A. perforatus-group (Coleoptera: Scarabaeidae: Aphodiinae: Eupariini). Acta Zool. Cracoviensia 44: 253-283.

SteBnicka Z. 2001c: Aphodiinae (Insecta: Coleoptera: Scarabaeidae). Fauna of New Zealand. Vol. 42. Manaaki Whenua Press, Landcare Research, Lincoln, Canterbury, N. Z., 64 pp.

SteBnicka Z. 2002: The New World Eupariini: Revision of the genus Auperia Chevrolat, 1864 (= Phalangochaeta Martinez, 1952) (Coleoptera: Scarabaeidae: Aphodiinae). Revue Suisse Zool. (in press).

Sternuerl E. 1872: Symbolae ad historiam Coleopterorum Argentinae meridionalis, ossia enumerazione dei coleotteri raccolti dal Prof. Strobel... Atti Soc. Ital. Sci. Natur. 15: $554-578$.

WoodrufF R.E. 1973: The Scarab Beetles of Florida (Coleoptera: Scarabaeidae). I. The Laparosticti (Subfamilies: Scarabaeinae, Aphodiinae, Hybosorinae, Ochodaeinae, Geotrupinae, Acanthocerinae). The Arthropods of Florida and Neighbouring Land Areas 8. Florida Department of Agriculture and Consumer Services, Bureau of Entomology, Gainesville, pp. 1-220.

Received May 5, 2002; revised July 20, 2002; accepted November 27, 2002 